\title{
Beyond Talent: The Powerful G's in the Life of Multitalented High School Students, A Phenomenology
}

\author{
Nida H. Garcia, Ed.D. \\ Technological University of the Philippines \\ Manila Philippines \\ Lorenzo C. Cortez \\ Rogsh Emmanuel H. Garcia \\ Edreign Pete G. Magdael \\ Lian Joshua H. Manongsong \\ Thrisha Nichole A. Carrios \\ Angelica Marie M. Talamante \\ Philippine School Doha \\ Doha, Qatar, PO Box 19664 \\ Research Development Accreditation and Publication Office \\ PSD, Doha Qatar \\ Research Capstone Project \\ PSD, Doha, Qatar
}

\begin{abstract}
Thetrue essence of being multitalented lies not in fame or success but in what multitalented individuals have become because of their talents. Capturing the lived experiences of a group of multitalented high school students, this qualitative phenomenological research has exposed the consequential evidence that plays around the life of multitalented students. Using an in depth semi-structured interview; the articulations of the respondents were gathered and transcribed from emic to etic. Emergent themes surfaced through cool to warm analysis of data via a dendogram were subjected to member checking procedure to ensure data trustworthiness. The phenomenological analysis of data revealed the Powerful G's in the life of multitalented students namely: the Greater Self, the Greater Good, and the Glorious Divine. These powerful G's reflect valuable life lessons that can positively influence anddirect human actions to deal with the daily challenges of life effectively andto live life meaningfully.
\end{abstract}

Keywords: Multitalented, Powerful G's, Greater Self, Greater Good, Glorious Divine, Phenomenology

\section{Introduction}

Life is a journey filled with significant lessons, joys and heartaches, celebrations and hardships, acceptances and rejections, sweet and bitter moments that will ultimately lead individuals to their exact destination and purpose in life (Bubna, 2019; Gulf Reporter, 2016; Ozturk, 2015; Spaunburg, 2014; Jackson, 2014; Maughmer,Jr., 2012). How individuals perceive the various circumstances in their day to day life, how much attention they pay to the significant lessons that life teaches them, and how the accumulations of these life lessons influence their decisions and actions shape their destination. Multitalented individuals just like any human beings go through this life journey. According to Johnston (2019) being smart, having lots of choices, driven with intensity and passion, create its own unique dilemma.The path of multitalented individuals, she added, involves understanding, overcoming, developing, expressing, and connecting. Having multitude of talents is not a sure way to success then. A fulfilling life is a perfect blend of an individual's unique self and rich experiences. Nedkova (2015) pointed out that people are all made of experience and natural strengths and that it is impossible to be born without any, or go through life without learning. She emphasized that each and every individual is born with the capacity and the capability to learn and hone one's skills as well as incorporate new expertise in another field. Chakrabarti (2019) justified that while individuals who are born with unique talents are blessed, talent alone can carry them only so far and that these individuals need to accompany talent with continuous hard work and great will power to shine through. 
Hence, while talents define what people can do, it is their outlook and attitude in life that regulate how well they can do things. In the same manner, it is how people maneuver their journey that determines how remarkable their life will be. Multitalented individuals have their stints of joys and trials as they journey in life. Benefits and challenges go with the use of their talents. Considered as a mixed blessings (Pfeffer, 2019) being multitalented can be both good and bad (Wijaya, 2017). This qualitative inquiry argues that while multitalented individuals are renowned and are recognized in their respective fields not everybody understands the kind of life they actually live. Though numerous articles have been written about giftedness, many multitalented people have been featured in books and magazines, and a considerable number of study have been conducted about them, this field of study remained to be underexplored. Hence, this phenomenological research attempts to capture the unique experiences of a select group of multitalented high school students as they put their talents into practice. This qualitative inquiry endeavors to uncover the consequential evidence that plays around their life being gifted with multitude of talents. Conceivably, the significant life lessons revealed in this study will be a source of hope, strength, and inspiration for others.

\section{Method}

\subsection{Research Design}

The study is qualitative in orientation and employs a phenomenological research design. A phenomenological research design is a study that attempts to understand people's perceptions and understanding of a particular phenomenon (Pathak, 2017). The fundamental goal of the approach is to arrive at a description of the nature of the particular phenomenon (Creswell, 2013). Phenomenological research design is utilized in this study to explicate the meaning, structure, and essence of the lived experiences of multitalented high school students of Philippine School Doha.

\subsection{Locus and Participants}

The respondents in this study were multitalented high school students of Philippine School Doha (PSD); a leading Filipino school in the State of Qatar. Six participants were involved in this study; four of whom were from the Senior High School Department and two were from the Junior High School Department. The respondents were selected through qualitative purposeful samplingstrategy (Creswell and Plano, 2011; Creswell, 2007; Bernard, 2002; Patton, 2002.) Selection of the study participants were based on the following criteria (a) respondents possess at least three talents, gift, skill or aptitude known to or liked by many specifically the students and teachers of PSD and (b) were studying in PSD either as a Junior or Senior High School student when the study was conducted. Of the six respondents, two were active members of a school club intended for students who have special skills in singing and dancing, three had represented the school in an international skill and talent contest and one is a known athlete and instrumentalist. All of them were acclaimed performers in school.

As this type of research requires close association and continuing relationships with the respondents in order to penetrate their life and experiences, only few participants were selected. According to Crouch (2013) a small number of cases of less than twenty will facilitate the researcher's close association with the respondents and enhance the validity of fine-grained, in-depth inquiry in naturalistic settings. Small samples of not more than ten respondents according to Van Manen, as cited by Garcia (2017) are most suitable for a phenomenological study as large samples can become heavy and increase the tendency of unmanageability.

\subsection{Data Collection and Ethical Consideration}

To capture the essence of this phenomenon, the researchers utilized a two-part form instrument. The first part was the robotfoto; meaning facial composite in the Dutch Language (Kelschtermans and Ballet, 2002) aimed to recognize the demographic sketch of the respondents namely gender, school, grade level, clubs or organization, special talents and skills. This was given to the respondents before the actual interview. The second part wasa semi-structured interview (Cohen, 2006) composed of a set of twenty-five item relevant and meaningful semi-structured questions which can provide reliable, comparable and qualitative data. The respondents were informed of how the research interview would be conducted, that it would last from thirty minutes to an hour and that their responses will be audio recorded for transcription and data interpretation purposes. The respondents were then reassured that their responses will be treated with utmost confidentiality.

\subsection{Data Analysis}

The researchers followed the inductive approach in theme development to establish clear links between the research objectives and the summary findings derived from the raw data (Thomas, 2003). The data analysis was divided into four parts. First, transcripts were read several times to extract the main points and ideas of the participant's insights. Then, the transcription of the respondent's point of view (emic) to the researcher's naïve understanding (etic) was done. The data from the participants were then grouped into similar themes and were analyzed thoroughly via a dendogram (Faulkner and Sparkes as cited by Acosta, 2010). 
Finally, a simulacrum was created wherein the findings and discoveries can be found in a form of a visual illustration. Themes emerged were subjected to member checking procedure and quadrangulation to make sure that the findings are credible, robust and well-developed.

\section{Findings}

Significant lessons in life are learned through various ways. Some are taught, some are acquired; some are learned the easy way, while others the hard way. As life is a cycle, so is the process of learning life lessons. It is unending, it never stops. It commences the moment a person is born and continues on as the person lives. An individual's daily life experiences offer important life lessons. These lessons in life enable one to become a better person not simply for himself or herself but also for others and ultimately for God.

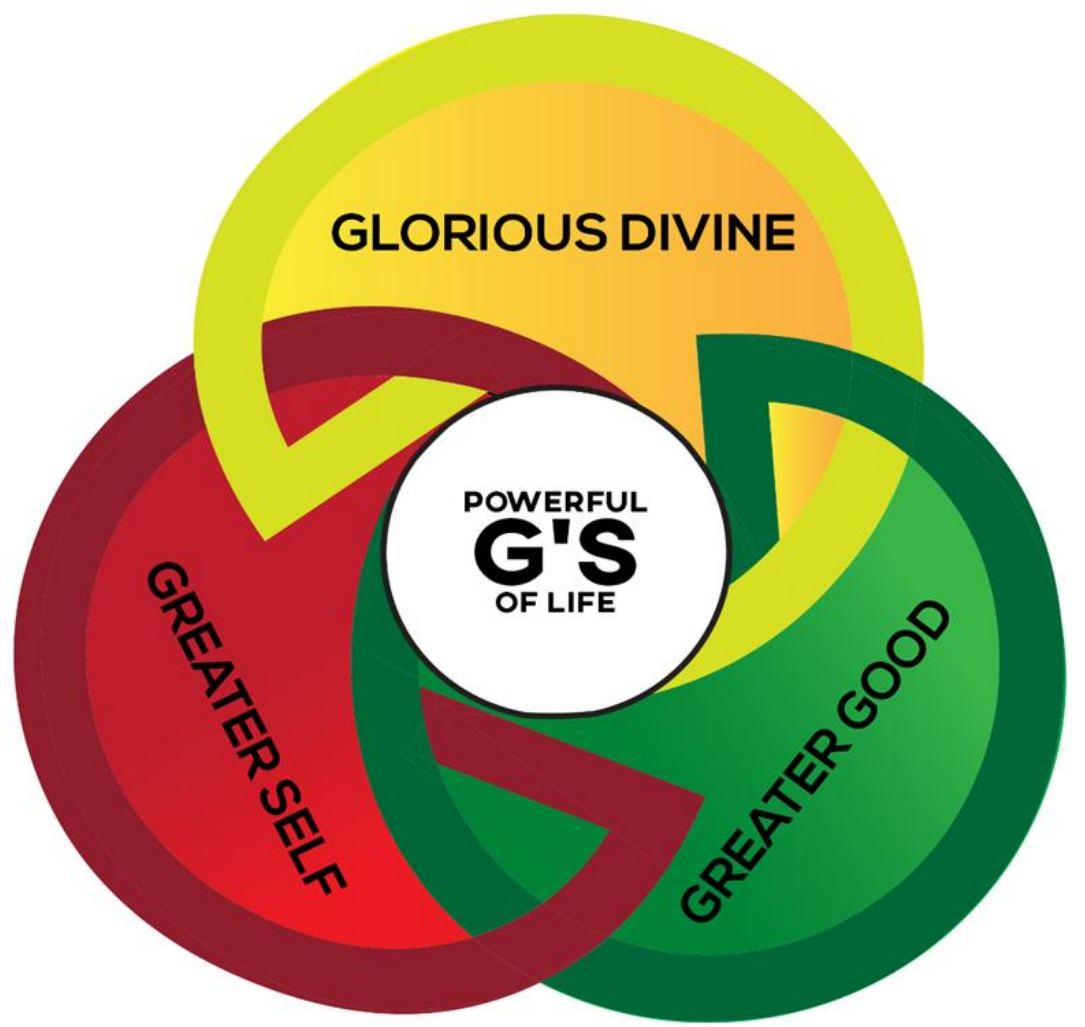

Figure 1: The Powerful G's Of Life

This figure displays the interconnection of the three significant life lessons revealed from the fascinating articulations, verbalizations, and musings of the respondents. The Powerful G's of life of multitalented students mirror valuable teachings that could be a source of strength, hope, and inspiration for others.

\subsection{Greater Self}

Multitalented students of Philippine School Doha, through the practice of their special talents and skills develop three powerful G's. These powerful G's are manifestations of major life lessons directed towards the development of a greater self, the promotion of greater good, and the exaltation of the glorious divine. Cultivating a greater self as revealed in the experiences of the respondents is all about loving oneself more, becoming better and moving forward. To love oneself more according to them is to have the courage to show who they really are, to do what they love to do, and to offer their achievements first and foremost to themselves. Respondents openly expressed:

"Be who you are, no matter what people say, no matter if they try to destroy you or say bad things about you. Just be yourself, surround yourself with positive people and have a positive outlook in life because everything gets better. We are all more than the negative things people say and we are strong individuals. We have thecapability to use our voice to spread a message to the world."

"Don't give up on the things that you love to do the most. Always trust yourself because it is you whom you can count on in times of needs." (MS4) 
The forgoing verbalizations speak of having a strong positive mind-set, of trusting oneself, never giving up in times of hardships, and affirming oneself through one's accomplishments conformed to by one student in the statement:" I dedicate these achievements to myself for just doing the things that I love to do." (MS5)

Proportionate to loving oneself more is becoming better as a person. This signifies honing one's expertise, being open to new experiences, working with passion and seizing every opportunity to utilize one's giftedness, and live life to the fullest. Three multitalented students recommended:

"Develop more of your God-given talents. Grab every opportunity; participate in activities you feel you can take part in. Do not hesitate to join; just go for it! At the end of the day, you will be thankful to find out that you have already developed your skills." (MSI)

"Give your heart to your talents. Pour every time you have in your passion because I guarantee that something great will happen... you will surely grow as a person. “(MS6)

"You only live once; don't hesitate to do the things you know you can do. If you know you are good at it, give more time to it, focus on it, use it and share it... for you live only once", (MS4)

Nonetheless, growing as a person and becoming better is not always as easy as it seems. There are downfalls, setbacks, shortcomings, and unclimbable walls. The musings and articulations of multitalented students of Philippine School Doha confirm though, that no matter how bumpy the road to self-improvement is, there is no other way to go but forward. Two students disclosed:

"We all have things to face and go through in life. We will all experience heartbreaks; we will all fail. We need to go through this process in order to achieve the things that we want to achieve in the future. We will surely get through all these for we are not alone. We simply need to press on."(MS2)

"You may have doubts on your potentials, it is normal to feel that way but don't let that feeling stop you from what you want to become because you need to overcome these doubts for they are part of the process of achieving what you want to be. Always grab the opportunity to hone your skills and don't hesitate to share your talents to people because these things will be your key to success." (MS3)

It is truly interesting to know how multitalented students traversed a unique path toward the cultivation of a greater self. More fascinating are the lessons learned in the process. The seemingly insurmountable challenges they come face to face with and the countless opportunities coupled with the limitless possibilities they have as gifted students, highlight their individuality as they strive to become the best and most unique persons they can possibly be. The road to the realization of the greater self maybe rough and bumpy but surely is full of unforgettable moments to have and to hold.

\subsection{Greater Good}

One of the greatest incentives multitalented individuals can have is the greater good. Referred to as the science of meaningful life, greater good is all about others. It talks about connection and compassion, kind-heartedness, and goodwill. In the culture of PSD's multitalented students it is spelled out in three benevolent actions; performing for a greater cause, upholding the philosophy of excellence, and giving back. As such, multitalented students perform not simply to show what they are good at. They go beyond themselves and use their very own experiences to inspire others. One respondent shared: "I actually really want to volunteer in delivering speeches because I want to share my experiences with others and help them develop as speakers." ${ }^{(M S 3)}$ They value meaningful performances such as those done for appreciation and representation as averred by one student:

"I also take pride in singing for the teachers during Appreciation Day and being able to perform well during last minute shows. As part of the dance troupe, we do not only perform in school, we also represent the school in outside events such as Qatar National Day." (MSI)

"We brought the banner of PSD to an interschool competition and we were the champions for the under 16 and under 19 brackets for the volleyball tournament." (MS4)

When asked what has been their greatest achievement, two multitalented students proudly claimed:

"The feeling of being of help to other people especially students..." (MS2)

"I think my greatest contribution would be when I represented the school in outside competitions. Through those competitions I uplifted the image of the school and was able to show that the school has diverse students who have different and strong capabilities that they can share to the world." (MS5)

The preceding narratives connote the sense of fulfilment respondents achieved not only through genuine service but also the prized opportunity to uphold the school's philosophy of excellence through high quality performance. Representing the school in various tournaments and competitions serve as an avenue to proudly wave the school's 
banner, uplift its image as an educational institution, and show everyone its wide array of intellectual and talented students the whole world can benefit from. In similar vein, this can be perceived as an act of giving back to the institution instrumental of one's total development. The feeling of gratitude though is not confined towards one school alone. Multitalented students are indebted to their families and friends for who they are and what they have become because of their talents. They sincerely expressed:

"I dedicate everything to my parents because they were the ones who were there since I was little and it's my time to pay them back for the effort and time they gave me." (MS4)

"I dedicate my achievements to my family because they helped and taught me a lot of things. Likewise, to my friends and the people that I love because they also play a big role in developing my personality and in enhancing my talents and they are always there for me." (MS5)

Certainly, multitalented individuals cannot perform their best and be at their best if they fail to attach meaning to what they are doing. Dedicating one's giftedness for the greater good is an influential lesson avenue where they can channel their performances and accomplishments.

\subsection{Glorious Divine}

Each individual has a unique relationship with God. Inherent or built, this relationship is improved and perfected through one's life experiences. Through the utilization of their special talents and skills and the numerous achievements and recognitions associated with their giftedness, multitalented students of Philippine School Doha have meaningful words to share with others particularly with their fellow students. These life lessons are reflected in the way they acknowledge God's power in their life, the act through which they offer their achievements to him and the manner they glorify the Glorious Divine. Respondents sincerely shared:

"Don't be shy to ask for help and guidance from the Almighty Father because he is the source of our strength and power to continue living and doing the things we do. “(MS4)

"I can do all things through Christ who strengthens me because I believe that everything that I do and have right now is because of God and His glory. I will not be able to do all of these things if not for Him." (MS5)

"Offer all your achievements to God; glorify Him and be thankful at all times. For once you give Him the glory; He will return the favor back to you. You will surely feel the blessings He would like to bestow upon you." (MSI)

Indeed, God plays a major role in the life of multitalented students. The confidence they have emanates from their faith and the belief that everything is possible with God. Through the recognition of Gods mighty power and great capacity to aid in honing their talents, multitalented students are directed to the path of thanksgiving and adoration. They show their gratitude and glorify God through their very own talents; recognizing Him as the source of all blessings received and those yet to come.

\section{Discussion}

\subsection{Greater Self}

Loving oneself is the beginning of endless possibilities. It is the key to getting anything and everything a person wants, serves as the foundation for finding inner peace and happiness andis recognized as a condition precedent to loving others (Ushedo, 2017; Deschene, 2013; Caldwell, 2019). Kotsos (2019) for her part expounded that loving oneself enables a person to make healthier choices and the best decisions across all areas of life, allows an individual to truly rejoice in other people's good fortune, and inspires one to be of greater service to the world at large. To love oneself therefore, is not simply about knowing and accepting oneself. It goes beyond the very concept of self-love to the discovery of the greater self.

The greater self as described by SGI (2019) is a sense of self that can fully identify and empathize with the suffering of others and is thus motivated to ease that suffering; an open, expansive character broadened by an empathy that extends not only to other people but to all forms of life to include the natural environment. It is self-grounded in a deep respect for the dignity of all life including one's own and the wisdom that perceives the inextricable interdependence of that life. According to WeTriump (2016) it is the essence of who a person is as he or she evolves through life. It cannot simply be equated to anything a person does, but it does foster the fertile landscape where one plants his or her dreams, relationships, and vision of best life. To nurture a greater self as revealed in the experiences of multitalented students is the act of redirecting one's spirit in order to love oneself more, become better, and be able to move forward.

"To be yourself in a world that is constantly trying to make you something else is the greatest accomplishment." Ralph Waldo Emerson, as cited in the book of Reklau, (2018) emphasized the value of loving oneself first, that is to accept oneself for who he or she is, to recognize one's value as a person, to be respected, and to feel great even without being perfect. 
In the experience of multitalented students, it is all about having the courage to show who they really are and do what they love to do without fear of intimidation, without fear of committing mistakes, and without worrying what other people will say about them. This implies that being oneself is a difficult process. An individual has to deal not only with social pressures but also with internal conflict. Anoua (2017) stressed that loving oneself has become a major challenge nowadays as people tend to be more concerned about the thinking and judgments of others rather than being honest and searching for an independent identity. This, according to Daskal (2016) is brought about by the fact that people want to be liked and appreciated for their many talents, their ferocious intelligence, their good nature, and their sparkling personality. Recognizing the danger this temptation may brought their life; described by Daskal (2016) as a vicious cycle of wanting to tailor one's life to fit the expectations of others which may eventually result to the sad reality of seeing oneself solely based on the perception of others; these multitalented students resist to turn over their power to the impressions of people. They nurture a strong positive mindset, continue to trust themselves, refuse to give up, and capitalize on their accomplishment as gifted individuals. This goes without saying that these multitalented students in the practice of their talents endure to cultivate self-acceptance and build their self-worth which according to Hibbert (2013)is the point of recognizing oneself to be greater than any other things and deeply knowing that as individuals they are of great value, that they are loveable, are necessary to this life, and are of incomprehensible worth.Moreover, to cultivate the greater self as cited by Bogen (2011) represents the natural human nobility characterized by a kind of compassion that is not only empathetic but also action-oriented. Hence, multitalented students recommended significant actions leading to becoming a better person. To be more competent is to level one's skills up, to be bold in the practice of one's talent and to grab every opportunity for improvement. Chua (2019) beautifully described actions similar to these as ways to becoming the person you truly love and adore. This is all about committing oneself to growth. As she expounded, the more a person grows, the better he / she becomes. The experiences of multitalented students speak of it in terms of living one's life to the fullest defined by Dean (2018) as the act of using one's experiences as means for personal growth and pushing the boundaries of oneself mentally, spiritually, and intellectually for the betterment of oneself and the world at large. It is all about continuously reaching out for newer, richer and life changing experiences. Steve Jobs (Chua, 2018) perfectly summarizes the pieces of advice multitalented students have for individuals like them in his words:

'Your time is limited; don't waste it living someone else's life. Don't be trapped by dogma, which is living the result of other people's thinking. Don't let the noise of other's opinion drown your own inner voice. And most important, have the courage to follow your heart and intuition, they somehow already know what you truly want to become. Everything else is secondary."

Finally, the discovery of greater self leads to no other direction but forward. Moving forward in life is not easy though. Every person, even the most successful ones feels lost and unmotivated at times. Everybody else falls into the trap of frustrations and self-doubt. The life experiences of multitalented students speak of the same thing. Many a times they fail and get hurt. These and many other negative experiences hold them back from moving forward but in the course of time lead them to significant decisions in life. As James (2019) emphasized, moving forward is a choice. No matter how many obstacles come along a person's life, it will be one's decision that will propel him / her forward. It is tantamount to saying that people are in control of their lives. No one therefore, should let himself / herself be trapped in the bubble of indecision. As Oprah Winfrey said(Fall, 2016); "Nothing happens until you decide.Make a decision and watch your life move forward." Multitalented students have their personal share of losing and winning, nevertheless they choose to shift their behavior and transform their life in order to discover and serve their greater self.

\subsection{Greater Good}

"Intelligence is not a privilege, it's a gift. And you use it for the good of mankind. 'The famous line of Dr.Otto Octavius from the movie Spider Man (Conley, 2017) summarizes the responsibility that goes with the power of intelligence. Being brilliant is not an entitlement but an endowment to be utilized for the good of others. This is likewise the standpoint of the Peter Parker principle “With great power comes great responsibility." These meaningful quotations imply of people's responsibility to give their talent to the world. As boldly stated by Conley (2013) everyone can become a spider man and improve the living conditions of those around them by harnessing their gifts and focusing on their strengths. The consequential evidence that plays around the life-experiences of multitalented high school students speak of the same thing. Their strong commitment to go beyond themselves to perform for a greater cause, uphold the philosophy of excellence, and give back are but simple manifestations of their great passion to serve the greater good. Multitalented students nurture their skills and strive to be the best version of themselves not simply for love of oneself but also for love of others. They showcase their talents for a greater cause; that is to inspire and help others develop their own unique abilities and giftedness. As Ramos (2017) pointed out, talents are meant to be shared with others. While people are gifted with unique talents, these talents are not just there for them. She highlighted that gifts and talents are purposely created in order for people to help those around them. 
Dinkmeyer and Losoncy (2017) justified that every time two people come in contact with each other, both individuals are influenced to move in either a more "turned on," encouraged direction or in a "turned off," discouraged direction. As such this entails trails leading to self-appraisal thus building pride and honor regarding the ability to excel at a certain track or field. Evans and Roberts (2012) explained further that children gain peer acceptance by excelling at something valued by other children. This serves as a correlative issue in regards to self-appraisal as a favorable reception to others. Hence, as emphasized by Siddiqui (2016) once a person discovers and learns how to use a specific talent; this should lead him / her towards making a great personal contribution to oneself and the society. The multiple gifts and talents within a person's disposal, the multiple opportunities and capacities he or she has, to aid others develop their own talents. Relative to the multitalented students' noteworthy acts to serve as inspiration for others is their commitment to excellence. They continuously hone their talents and give their best performance at all times in order to bring pride to the school through representations and standing out during competitions. Gallardo-Gallardo, et. al. (2013) described it as individuals' willingness to invest discretionary energy into an organization's success thus aligning personal with organizational goals. In similar veins, the quest for excellence is coupled with a deep sense of appreciation and feeling of indebtedness. Multitalented students look back and give homage to their roots. This is beautifully expressed by Allen (2018) as the experience of gratitude which encourages people to appreciate what is good in their lives and compels them to pay this goodness forward. The study conducted by Kang and Rafaelli (2015) explored young adults' sense of indebtedness to parents and their appreciation for their parents' hardship and sacrifice. Dedicating one's achievement to the people who in one way or another have assisted, guided, and inspired them towards the realization of their dreams is a form of gratitude which Allen (2018) further described as a social glue that nurtures the formation of new friendships, enriches existing relationships, and underlies the very foundation of human society.

Overall, it is inspiring to note how multitalented students through their unique individual skills and talents contribute to the realization of the greater good. The opportunity to perform for inspiration, execute for excellence, and achieve for a cause greater than oneself will surely make a difference not only in the lives of the people they value but the society as a whole.

\subsection{Glorious Divine}

Man is in constant search for meaning. Everyone as stressed by Ackerman (2018) hunger for meaning, for purpose, for the feeling that life is worth more than the sum of its parts. An individual intuitively know that he wants meaning in his life and that meaning helps him survive. People, however, attach different meanings to the so called 'meaning of life'. Kumbakonam, et. al. (2017) pointed out that the object of life is simply to achieve the greatest possible comfort and prominence in the world. On the contrary, Emerson stressed that the purpose of life is not just to be happy but to be useful, to be honorable, to be compassionate, to make some difference that one has to live and lived well (Foroux, 2019). Hence, there are those who view life's purpose as a spiritual concept, something of religious dimension (Leider 2015 ) and is thus associated with one's connection to the divine.

Undeniably, multitalented students find solace in loving themselves, they find joy in serving others; nevertheless, love for oneself and others do not capture in full the kind of life they live. Their heart overflows with gratitude to God to whom they anchor their strength; the ONE who hold them steadfast. This is described by Warren (2013) as the act of surrendering and entrusting oneself to God. In the context of the experiences of multitalented students, it is the strong will to put their life under the control of the glorious divine and the great desire to glorify Him.

Needless to say, multitalented students believe that God is the source of everything. They acknowledge that their unique abilities, talents and gifts all come from God. These and more as cited by Warren (2017) represent a person's SHAPE: spiritual gifts, heart, abilities, personality, and experiences. These, he added, are the bundle of talents God has given people that makes them who they are and sets them apart from others. To be able to use these talents to the fullest, as exemplified in the life of multitalented students, one has to have a special relationship with God. Having a real, intimate relationship with God as narrated by Ingram (2019) is not just about using the "right" words, spiritual techniques, twisting God's arm, or trying to live a perfect life. Anderson-Little (2016) attached a deeper meaning to it. According to her, the only thing that changes the world is when people of faith deepen the conviction that comes from their own unique relationship with God and share it with others by embodying a life of faith. This is all about offering every detail of one's life to God knowing and believing that He makes all things possible under all circumstances. If one agrees that God is trustworthy he / she should embrace His promises and stop worrying (Chambers, 2019; Gaouette , 2017; and Stalnacke, 2013). This, as exemplified in the life of multitalented students is complete recognition of God's mighty power and total dependence on His divine provision. 
Indeed, God's goodness is infinite and His love is beyond measure. Recognizing God's faithfulness in their life, multitalented students make effective use of their God-given gifts and humbly offer their achievement to God. Ken Boa writes and Whelchel(2018) quoted;

"God has entrusted us with certain resources, gifts and abilities. Our responsibility is to live by that trust by managing these things well, according to his design and desire."

Definitely, this is all about making use of one's talents and skills according to God's purpose. Buscaglia on his part expounded that people's talent is God's gift to them. What they do with it is their gift back to God. This implies the accountability that goes with the gift of talents. How an individual develops his/her talents, how he/ she makes use of them and whatever he / she accomplishes out of these gifts are means by which and through which one can return the favor to God. Multitalented students consider the wise use of their gifts as an avenue to thank and glorify God for His goodness. They play, they sing, they dance, they design, they create, and recreate daily for God's glory.

In the end, what matters most is how well people live their life. To use it for God's glory is the only right thing to do. As concluded by Payne (2019) to live is to bring glory to God because there is no one greater who is worthy of trust, adoration, and worship but Him. Life, after all is not simply about anyone. It's all about God and his amazing grace.

\section{Conclusion}

Indeed love can change the world. Its power, particularly when borne out of significant human experiences associated with being multitalented cannot be underestimated however should be shared and emulated. The powerful G's namely: the greater self, the greater good, and the glorious divine that emerged in the lived-experiences of Philippine School Doha's high school multitalented students are revelations of the consequential evidence directly or indirectly resulting from the practice of their special skills and talents. The extent to which the love for oneself, for others and for God is influenced by the use of their talents is not certain thus can be a basis of further studies but the significant truths and life lessons revealed in the study can definitely guide people, specifically teenagers and young adults all over the world in their everyday action.

Capitalizing on the power of phenomenology, this study has beautifully captured the significant life lessons a select group of multitalented students learned in the practice of their multiple skills and talents. The multitalented students' powerful G's of life reflect valuable teachings that can serve as a source of strength, hope, and inspiration for others. The greater self reminds multitalented students of the exceptional value of loving oneself and its connection to the realization of their dreams and the achievement of their best vision in life. The greater good invites them to go beyond themselves and make use of their giftedness for the good of others and the betterment of mankind. Lastly, the glorious divine gives meaning to their existence and offer answer to the many questions they come across with in the practice of their talents. Presumably, these powerful G's act as propeller in the life of multitalented students, igniting them to action, thrusting them forward, keeping them in pace, and enabling them to rise above all life pressures and challenges. Indeed, there are lessons in life which can be best learned through experience. The themes uncovered in the lived experiences of multitalented high school students serve as powerful lens directing and influencing human actions. Their personal reflections and realizations offer other teenagers and young adults significant insights on how to live one's life meaningfully and how to deal with the ups and downs of life effectively. The powerful G's beautifully capture the affirmative principles multitalented students live by, yet are not absolute guarantee of a happy and successful student life. Hence, schools, teachers, and parents alike should take proactive moves to explore the world of multitalented students, understand the kind of life they live, offer them the best possible support and provide endless opportunities for them to harness their full potential for them to live a well-balanced and truly satisfying life for themselves, for others, and for God.

Although the findings in this study highlight the consequential evidence that plays around the life of multitalented high school students, it is inevitable for some concepts to be overlooked. This study, therefore, opens possible research opportunities and invites researchers to conduct a follow-up research to find out what have become of these students after graduating from high school. Quantitative research can likewise be conducted to support the findings in this study. Results can accurately determine the degree of correlation between the emergent themes and that of being multitalented and can possibly generate other significant findings.

\section{References}

Ackerman, C. (2018, February 13). What is the Meaning of Life According to Positive Psychology [2019]. Retrieved from https://positivepsychology.com/meaning-of-life-positive-psychology/ 
Acosta A (2010). From emotional flame to moral frame: A phenomenology of the reflective mediation practice of Philippine School Overseas, Dissertation by Articles, Published Internationally, University of Santo Tomas Graduate School Studies.

Allen, S. (2018). The Science of Gratitude. Retrieved from Greater Good Science Center at UC Berkeley website: https://ggsc.berkeley.edu/images/uploads/GGSC-JTF_White_Paper-Gratitude-FINAL.pdf

Anderson-Little, L. (2016). Your Unique Relationship with God. Retrieved from https://www.soulstorywriter.net/64your-unique-relationship-with-god

Anoua, H. (2017, July 7). The Art of Being Oneself. Retrieved from https://flevy.com/blog/the-art-of-being-oneself/

Bernard HR (2002). Research methods in anthropology: Qualitative and quantitative methods. 4th edition. AltaMira Press, Walnut Creek, California (Chapter 9).

Bogen, M. (2011). Report from the 8th Ikeda Forum for Intercultural Dialogue (10-2011). Retrieved October 13, 2019, from http://backupmail.brc21.org/current/greaterself_ikedaforum2011_article.htm

Bubna, S. (2019, May 27). Life Is A Journey. Retrieved from https://wrytin.com/simranbubna/life-is-a-journeyjw6hmp81

Buscaglia, L. (n.d.). "Your talent is God's gift to you. What you do with it is your gift back to God." Leo Buscaglia. Retrieved October 19, 2019, from https://thepinkandsparklyblog.blogspot.com/2012/07/your-talent-is-godsgift-to-you-what.html

Caldwell, Cam. (2019). Loving Oneself and Its Importance in Relationships.

Chakrabarti, S. (2019, February 25). 10 Quotes on Nurturing Talent. Retrieved from https://life11.org/2015/01/28/10quotes-on-nurturing-talent/

Chambers, O. (2019). The Habit of Recognizing God's Provision | My Utmost For His Highest. Retrieved from https://utmost.org/the-habit-of-recognizing-god\%e2\%80\%99s-provision/

Chua, C. (2018, August 24). 11 Life Lessons to Learn From Steve Jobs. Retrieved from

https://personalexcellence.co/blog/steve-jobs/

Chua, C. (2019). 101 Ways to Be A Better Person. Retrieved from https://personalexcellence.co/blog/101-ways-to-be-abetter-person/

Cohen D, Crabtree B (2006). "Qualitative Research Guidelines Project." July 2006. http://www.qualres.org/HomeSemi-3629.html

Conley, N. (2013, 28). Spider-Man 2: Because We Found the Rubber Band. - Nicholas Conley. Retrieved October 18, 2019, from https://nicholasconley.wordpress.com/2013/03/28/spider-man-2-because-we-found-the-rubberband

Conley, N. (2017). Best Supervillain Quotes In Comic Book Movies | Screen Rant. Retrieved from https://screenrant.com/best-supervillain-quotes-lines-comic-book-superhero-movies

Creswell JW, Plano Clark VL (2011). Designing and conducting mixed method research. 2nd Sage; Thousand Oaks, CA.

Creswell JW (2007). Qualitative inquiry \& research design: Choosing among five approaches. Thousand Oaks, CA: SAGE Publications.

Creswell, J.W. (2013). Qualitative Inquiry \& Research Design: Choosing Among the Five Approaches. Thousand Oaks, CA: SAGE Publications, Inc. (pp. 77-83)

Crouch M (2013). The logic of small samples in interview-based qualitative research. Journal Citation Reports®, Thomson Reuters, 2014, Sage Publication.

Daskal, L. (2016, May 12). How to Stop Worrying What Other People Think of You. Retrieved from https://www.inc.com/lolly-daskal/how-to-stop-worrying-what-other-people-think-of-you.html

Dean, Z. (2018). Lessons Learned from the Path Less Traveled Volume 1: Get Motivated and Overcome Obstacles with Courage, Confidence and Self-Discipline.

Deschene, L. (2013). Tiny Buddha's Guide to Loving Yourself: 40 Ways to Transform Your Inner Critic and Your Life. Berkeley, CA: Conari Press.

Dinkmeyer, D., \& Losoncy, L. (2017). Skills of Encouragement Bringing Out the Best in Yourself and Others (1st ed.). Retrieved from https://doi.org/10.1201/9780203739617

Evans, J., \& Roberts, G. (2012, March 19). Physical Competence and the Development of Children's Peer Relations. Retrieved from https://shapeamerica.tandfonline.com/doi/abs/10.1080/00336297.1987.10483854\#.XafgQegzbIV

Fall, P. (2016). "Make a decision and watch your life move forward.". Retrieved October 14, 2019, from http://redesigning-your-life.com/2016/01/make-decision-watch-your-life-move-forward/

Foroux, D. (2019, August 2). The Purpose Of Life Is Not Happiness: It's Usefulness. Retrieved from https://medium.com/darius-foroux/the-purpose-of-life-is-not-happiness-its-usefulness-65064d0cdd59 
Gallardo-Gallardo, Eva \& Dries, Nicky \& González-Cruz, Tomás. (2013). What is the meaning of 'talent' in the world of work?. Human Resource Management Review. 10.1016/j.hrmr.2013.05.002.

Gaouette, T. M. (2017, October 14). How to Recognize Your Blessings. Retrieved from https://www.projectinspired.com/how-to-recognize-your-blessings/

Garcia, N. H., \& Acosta, A. S. (2017). From Leadership Attribution to Leadership Contribution: Proversified Leadership Skills and Abilities of Philippine Schools Overseas (PSO's \} Administrators. IJEPRR, 4, 169 - 179. doi:10.15739 IJEPRR.17.018

Gulf Reporter. (2016, April 23). LIFE IS A JOURNEY. Retrieved from https://www.kannadigaworld.com/news/karavali/252148.html

Hibbert, C. (2013). Self-Esteem vs. Self-Worth: Q \& A w/ Dr. Christina Hibbert. Retrieved from https://www.drchristinahibbert.com/self-esteem-vs-self-worth/

Ingram, C. (2019, June 14). The Secret to a Close Relationship with God. Retrieved from https://livingontheedge.org/2013/01/21/the-secret-to-a-close-relationship-with-god/

Jackson, C. (2014, April 1). Life Is a Journey: Enjoy the Ride. Retrieved from https://guardianlv.com/2014/04/life-is-ajourney-buckle-up-and-enjoy-the-ride/

James, S. (2019, January 10). Moving Forward: 8 Proven Tips to Move Forward in Your Life. Retrieved from https://projectlifemastery.com/moving-forward/

Johnston, E. (2019). Personal Development of Multi-Talented Individuals. Retrieved from https://www.selfgrowth.com/articles/personal-development-of-multi-talented-individuals

Kang, H., \& Rafaelli, M. (2015, January 20). Personalizing Immigrant Sacrifices: Internalization of Sense of Indebtedness Toward Parents Among Korean American Young Adults - Hyeyoung Kang, Marcela Raffaelli, 2016. Retrieved from https://journals.sagepub.com/doi/abs/10.1177/0192513x14567955

Keltchtermans G, Ballet K (2002). The micropolitics of teacher induction a narrative bibliographical study on teacher socialization. Teaching andTeacher Education, 18(1), 105-120.

Kotsos, T. (2019). Self Love - The Greatest Love of All. Retrieved from https://www.mind-yourreality.com/self_love.html

Kumbakonam, Usha \& Usha, K \& Assistant, Rani. (2017). Real Purpose of Life. Research Journal of English. 2. 6-9.

Leider, R. J. (2015). The Power of Purpose: Creating Meaning in Your Life and Work. Oakland, CA: Berrett-Koehler Publishers.

Maughmer, Jr, M. (2012, September 7). What Do You Do When You Find Yourself Sitting By The Side Of The Road. Retrieved fromhttps://www.sermoncentral.com/sermons/what-do-you-do-when-you-find-yourself-sitting-bythe-side-of-the-road-melvin-maughmer-jr-sermon-on-faith-169559

Nedkova, V. (2015, October 1). You have plenty of talents, skills, and passion. Don't ever say otherwise. — Violeta Nedkova. Retrieved from https://violetanedkova.com/blog/2015/9/29/talents-skills-passion

Ozturk, B. (2015). "Life is an interesting journey...". Retrieved from https://www.linkedin.com/pulse/life-interestingjourney-whatever-dont-kill-you-makes-bilal

Pathak, V., Jena, B., \& Kalra, S. (2017). Qualitative research. Perspectives in Clinical Research, 4(3), 192. doi:10.4103/2229-3485.115389

Patton MQ (2002). Qualitative research and evaluation methods. 3rd Sage Publications; Thousand Oaks, CA.

Payne, K. (2019, June 18). The Simple Guide To Find Your God Given Purpose In Life. Retrieved from https://kevintpayne.com/the-simple-guide-to-find-your-god-given-purpose-in-life/

Pfeffer, H. (2019). The Too Many Aptitudes Problem. Retrieved from http://megasociety.org/noesis/138/aptitude.html

Ramos, K. (2017, August 16). 7 Inspiring Reasons Why You Should Use Your Talents or Gifts. Retrieved from https://medium.com/thrive-global/7-inspiring-reasons-why-you-should-use-your-talents-or-gifts$79 \mathrm{~d} 5063 \mathrm{~d} 4 \mathrm{c} 4 \mathrm{e}$

Reklau, M. (2018). Love Yourself First! Boost Your Self-Esteem in 30 Days. Change Your Habits, Change You.

Siddiqui, F. (2016). The Importance of Using Your Talents. Retrieved from http://selfimprovementtips.expertscolumn.com/article/importance-using-your-talents

Soka Gakkai Malaysia (SGI). (2019). The Greater Self. Retrieved from http://www.sgm.org.my/en/?cur=page/page\&id=306\&title=The_Greater_Self

Spaunburg, S. (2014). Life is a Journey. Retrieved from http://www.besttolive.org/life_journey.html

Stalnacke, M. (2013, November 7). Blessings from Recognizing God's Greatness. Retrieved from http://www.flowingfaith.com/2011/11/blessings-from-recognizing-gods-greatness.html 
Thomas, D. R. (2003). (PDF) A General Inductive Approach for Qualitative Data Analysis. Retrieved March 8, 2019, from https://www.researchgate.net/publication/228620846_A_General_Inductive_Approach_for_Qualitative_Data_ Analysi

Ushedo, S. (2017, December 7). Self-Love Is the Key to Getting Anything and Everything You Want. Retrieved from https://www.huffpost.com/entry/selflove-is-the-key-to-ge_b_8012050

Warren, R. (2013). The Purpose Driven Life Journal: What on Earth Am I Here For?

Warren, R. (2017, August 17). Make the Most of Your Talents. Retrieved from https://pastorrick.com/devotional/english/make-the-most-of-your-talents

We Triumph. (2016, August 6). Evolving into Your Greater Self. Retrieved from http://wetriumph.net/evolving-intoyour-greater-self/

Whelchel, H. (2018, December 14). Do You Know the Purpose for Your Gifts and Talents? Retrieved from https://tifwe.org/the-purpose-gifts-and-talents/

Wijaya, P. (2017, September 5). Multi-talented: Good or Bad? Retrieved from https://philipwijaya.com/2013/12/19/multi-talented-good-or-bad/ 